Article

\title{
A Refamilialized System? An Analysis of Recent Developments of Personal Assistance in Sweden
}

\author{
Dietmar Rauch *, Elisabeth Olin and Anna Dunér \\ Department of Social Work, University of Gothenburg, 40530 Gothenburg, Sweden; E-Mails: dietmar.rauch@socwork.gu.se \\ (D.R.), elisabeth.olin@socwork.gu.se (E.O.), anna.duner@socwork.gu.se (A.D.)
}

* Corresponding author

Submitted: 12 January 2018 | Accepted: 9 February 2018 | Publication: 17 May 2018

\begin{abstract}
The Swedish system of disability support is often praised for its comparably well-developed Personal Assistance (PA) scheme. PA is formally prescribed as a social right for disabled people with comprehensive support needs in the Act Concerning Support and Services to Persons with Certain Functional Impairments (LSS). In the decade following the introduction of LSS in 1994, the PA-scheme expanded steadily to accommodate the support needs of more and more disabled people. It is commonly believed that the expansion of PA has substantially boosted the agency of both disabled people and their relatives. This article critically discusses in what direction the Swedish system of disability support has moved in the past decade. Is the common image of a system moving towards an ever increasing defamilialization of disability support still accurate? Or are there signs of stagnation, or even reversal towards refamilialization? What are the possible consequences of the more recent developments for disabled people and their relatives in terms of agency and equality? These questions will be discussed with the help of an analysis of the regulatory framework of disability support, statistical data and findings from public reports.
\end{abstract}

\section{Keywords}

agency; assistance allowance; defamilialization; disability support; equality; familialism; personal assistance; Sweden

\section{Issue}

This article is part of the issue "Global Perspectives on Disability", edited by Shaun Grech (The Critical Institute, Malta) and Karen Soldatic (Western Sydney University, Australia).

(C) 2018 by the authors; licensee Cogitatio (Lisbon, Portugal). This article is licensed under a Creative Commons Attribution 4.0 International License (CC BY).

\section{Introduction}

Traditionally, the support of disabled people was almost exclusively a family matter with very little involvement of other agents. Only since the rise of modern welfare states from the late 19th century, certain states started to accept a limited public responsibility for the support needs of disabled people and, consequently, residential service facilities for this group started to emerge. From the second half of the 20th century, in many countries, the public support responsibility was widened to cover a larger proportion of disabled people and, in part as a reaction to the claims of the Independent Living Movement (Askheim, Bengtsson, \& Bjelke, 2014), the major form of support changed from residential facilities to home-based support services.

This partial transfer of support responsibility from the family to the state has by some been coined as defamilialization (e.g., Lister, 1994; McLaughlin \& Glendinning, 1994). In comparative studies about social service regimes, the Scandinavian countries are usually characterized as outstanding pioneer cases concerning their capacity to defamilialize support (e.g., Esping-Andersen, 1999; Lewis, 2001), mainly due to their comparably welldeveloped public childcare and eldercare systems (e.g., Sipilä, 1997; Anttonen, 2003). Less has been written about disability support regimes from a comparative perspective. Yet, the available studies suggest that the Scan- 
dinavian countries have achieved a comparatively high degree of defamilialization also when it comes to disability support. In these studies (e.g., Askheim et al., 2014; Szebehely \& Trydegård, 2007), the role of the Swedish Personal Assistance (PA) system in particular, introduced in the Act Concerning Support and Services to Persons with Certain Functional Impairments (LSS) has been emphasized. The intention with the reform was to advance self-determination and participation in society for people with comprehensive support needs.

The main aim of this article is to critically discuss in what direction Swedish disability support in the form of PA has been heading in the past decade when it comes to the balance of support responsibility between the public sector and the family. Is the common image of a system that is moving towards more and more defamilialization of support still accurate? Or are there signs of stagnation or even reversal towards refamilialization? What are the possible consequences of the recent developments in the Swedish PA-system for both disabled people and their relatives in terms of agency and equality?

In the following section the theoretical framework of this article will be sketched out. In particular, the concept of defamilialization will be discussed here. Thereafter the data and methodology of the study are described. Subsequently, the main formal traits of the Swedish disability support system since the introduction of the LSS in the mid-1990s will be illustrated, followed by an analysis of the development of PA in the past 10 years, based on public statistics and public reports. Finally, the possible consequences of these developments in terms of equality and agency for support givers and recipients are discussed before the main findings will be wrapped up in the conclusion.

\section{Theoretical Concepts}

\subsection{Defamilialization}

One of the main tasks of modern welfare states is to provide services to those needing practical and/or personal support. The main target groups of these services are children, older and disabled people. Probably the two most important functions of these services are: (1) to make sure that the needs of support are properly met, and (2) to lessen the dependency of (potential) familial support givers and support recipients from each other (Rauch, 2007).

In theoretical terms, the second function can be approached with the concept of defamilialization, initially developed by Ruther Lister (1994) and defined as "the degree to which individual adults can uphold a socially accepted standard of living, independently of family relationships" (Lister, 1994, p. 37). While Lister originally mainly focused on economic aspects of defamilialization (i.e., financial/economic autonomy), the focus in this article will shift to the question of social dependency between (potential) familial support-givers and support- recipients. One basic assumption here is that a familial support relation increases the dependency of both parties (Dunér \& Olin, 2018; McLaughlin \& Glendinning, 1994). If support-giving is at least partially transferred to other actors outside the family-in other words, if it becomes defamilialized-the personal autonomy and agency of both support-givers and support-recipients will be elevated (Leitner \& Lessenich, 2007; O'Connor, 1993; Ulmanen, 2015). Here, familialized support is in no way regarded, in itself, as an inferior or undesirable form of support. Of course, familial support is essential for many disabled people. Some do prefer familial support and emphasize its intrinsic value. Others have a more ambiguous stance towards it. And yet others do prefer public or other types of support (e.g., Dunér \& Olin, 2018). The very point is rather that real agency of support-givers and support-recipients presupposes that disabled people and their relatives have a real chance to choose the support form they desire.

Many articles on social services calculate or relate to overall defamilialization scores for certain care schemes in order to analyze the impact of these on agency and equality (e.g., Esping-Andersen, 1999; Lohmann \& Zagel, 2015; Rauch, 2007). However, it is often overlooked that defamilialization can be distributed unequally across different social groups in society. Depending on the institutional structure of the support solution in question, some segments in society might gain more defamilialization of support than others. In this article we will explicitly address this question by introducing the concept of segmented defamilialization, understood as defamilialization which is only granted to some groups in society (e.g., social classes, citizens of certain regions, etc.) but not, to the same degree, to others.

\subsection{Agency and Equality}

In this article, the concept of defamilialization will be tightly linked to concepts of agency and equality. Equality presupposes according to Amartya Sen (1992) not only equal access to material resources but also equality of agency. Agency will be defined here as the ability of individuals to make their own choices. Defamilialized disability support can be argued to raise the agency of both disabled people and their relatives. The availability of extra-familial support options grants close relatives greater agency to choose to what extent they would like to dedicate their time to the support of their disabled relative or rather to alternative activities, such as labor, leisure, and so on. Likewise, defamilialized support options give disabled people the agency to choose between different support forms. They might want to choose extra familial support if they deem that this support form increases their independency in society more than familial support. To sum up, defamilialized disability support has the capacity to enhance the richness in terms of agency among both groups and thus improves their social position in relation to other groups in society. In other words, 
it can contribute to increase the equality between those who are disabled and those who are not.

\section{Data, Operational Assumptions and Analytical Framework}

The discussions in this article will be based on analyses of legal regulations concerning PA, public statistics and findings from public reports. In the first step of analysis, the legal framework of PA and the related Assistance Allowance ( $A A)$ will be discussed. In the second and main step of analysis, public statistics from, among others, the Swedish Social Insurance Agency (SSIA) and the Swedish National Board for Health and Welfare (NBHW) will be used to study the development of PA since the introduction of LSS in the mid-1990s. Here, focus will be on the development of the number of PA-recipients per capita, approval rates and withdrawn PA-admissions, as well as on the average amount of assistance hours granted per recipient. A combined analysis of these indicators will be used to discuss developmental trends concerning the degree of defamilialization of disability support in general and among different social groups. The main underlying operational assumptions are:

(1) Relative number of recipients: the higher the relative number (share per 100.000 residents) of PArecipients, the higher is ceteris paribus the overall share of people with disability receiving at least partially defamilialized assistance;

(2) Approval and withdrawal rate: the higher the share of declined PA-applications and the higher the share of withdrawn PA-admissions, the higher is ceteris paribus the share of people wishing to receive but being excluded from getting defamilialized assistance;

(3) Service intensity: the higher the number of PAhours per PA-recipient, the deeper is the degree of support defamilialization among those receiving PA.

The quantitative data will be interpreted with the help of SSIA'S own enquiries about the development of AA. This allows us to better understand alterations over time concerning admission assessments.

Taken together, the first two steps of analysis will help us to identify defamilialization or refamilialization trends in Swedish disability support. The third step of analysis, which will mainly be based on a report from the NBHW, can give us tentative findings about possible consequences of these developments for the agency of both familial support-givers and support-recipients as well as the social position of these two groups in relation to other groups in society.

\section{The Legal Framework: LSS and the System of PA}

A major legal cornerstone of the Swedish system of disability support is the LSS introduced in 1994. LSS de- fines three target groups for disability support measures (SFS, 1993): persons with learning difficulties, autism or a condition similar to autism (group 1), persons with significant pervasive cognitive impairment related to brain damage acquired in adult life due to external violence or physical sickness (group 2), and people with other permanent physical or mental impairments not due to normal aging causing significant difficulties with daily life activities and therefore a substantial need of support and service (group 3) (LSS, 1§).

All persons in these three groups are to be granted certain social rights if they need support for their living and their needs are not met in other ways (LSS, 7§). Probably the most important social right (and the one I will focus on in the following) specified in LSS is the right to PA. PA is according to LSS (9a§) to be granted to individuals from the three categories mentioned above, provided the conditions of LSS $7 \S$ are fulfilled, if they are because of large and consistent impairment need help with either: (1) their personal hygiene, (2) meals, (3) getting dressed and undressed, (4) communication with others or (5) other assistance requiring detailed knowledge of the person.

The right to PA is intimately linked to the so-called $A A$, administered by the SSIA and jointly financed by the state and local municipalities. AA is to be granted to individuals qualifying for PA according to the regulations above, if they are regarded to need assistance in accordance with LSS 9a§ more than 20 hours per week. Other personal needs may be counted in as well (SSIA, 2017b). If granted, $A A$ is to be used by the beneficiaries to finance their PA. AA-admission is to be re-evaluated and, consequently, can be withdrawn, reduced, remain unchanged or expanded each second year. People who are regarded to need less than 20 hours of PA, can still be entitled to PA fully administered and financed by local authorities (in short, municipal PA). About $75 \%$ to $80 \%$ of all current PA-recipients are covered by AA (SSIA, 2017a).

There is no doubt that the introduction of LSS has sparked a tremendous rise of PA in the period 1995-2010 (see Figure 1). However, in recent years several administrative court rulings and governmental appropriation directives may have influenced the development of $P A$ in a reverse direction (NBHW, 2017b; SSIA, 2017b). To assess the impact of these recent de facto changes of the regulatory framework of PA we will discuss statistical data concerning PA-coverage, approval rates, withdrawal decisions and service intensity.

\section{Analysis of the Development of PA-Coverage, Approval Rates, Admission Criteria and Service Intensity}

Figures for the development of PA are available since 1994. They indicate that the total number of PArecipients (comprising both AA-recipients and recipients of municipal PA) has increased steadily from the introduction of LSS in 1994 up until about 2010-2011. Also, the 


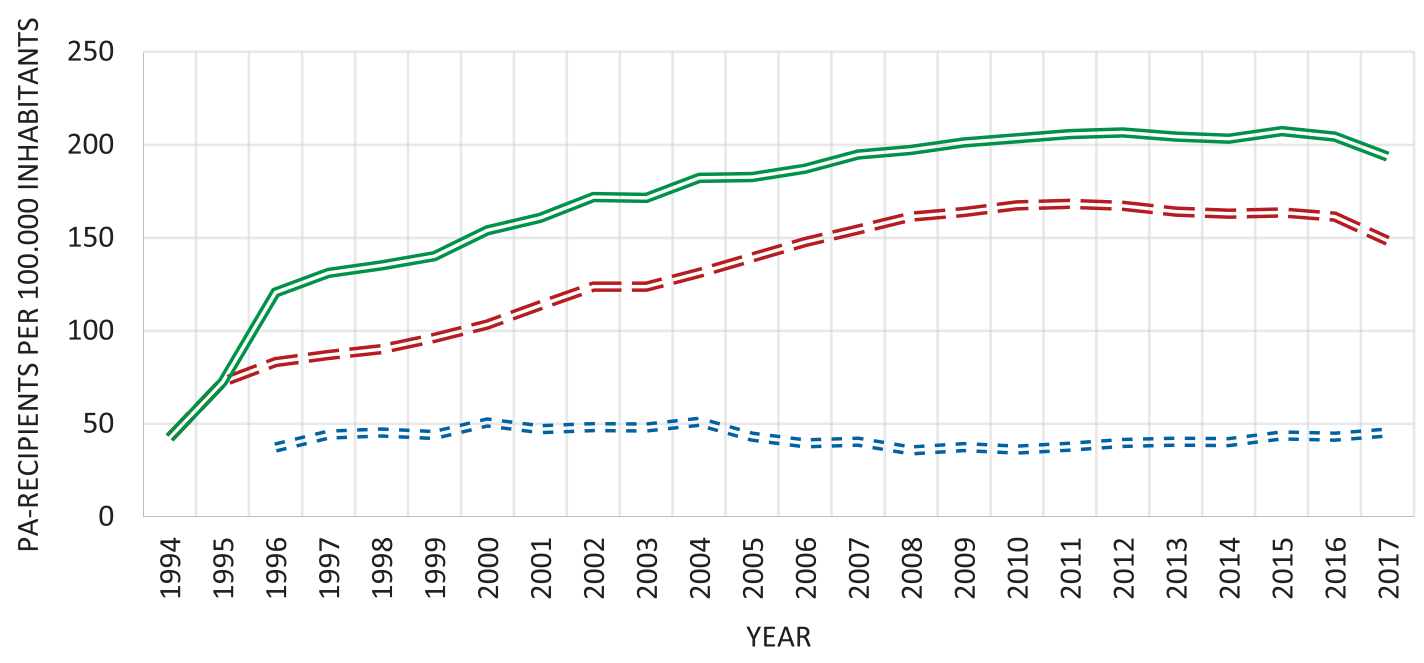

$==$ : AA-recipients $=\mathbf{=}=\mathbf{s}$ : Municipal PA-recpients $=$ All PA-recipients (AA + municipal PA)

Figure 1. Relative number of PA-recipients, 1994-2017. Sources: own calculations based on Statistics Sweden (2018), SSIA (2017a) and NBHW (2017a); data from SSIA retrieved from Independent Living Institute (2018).

overall amount of admitted PA-hours has risen throughout this period, as well as the number of hours allocated per PA-recipient. Altogether, this early period of PA-development, can be described as a period of constant growth (SSIA, 2016). The main question to address below is what happened since then.

\subsection{The Relative Number of Recipients: A Proxy for PA-Coverage}

It is virtually impossible to exactly calculate coverage levels for disability support schemes, since there are no reliable figures about the number of disabled people and their support needs. However, assuming that there are no major short-term fluctuations in this group, the development of the relative number of recipients of PA (number of recipients per 100,000 inhabitants) can serve as a proxy to grasp trends in coverage development.

The relative number of PA-recipients has risen steadily up until about 2010-2011 (see Figure 1). From this point of time we can see a stagnant trend until about 2015 and a decline for the most recent period until 2017. This decline is due to a shrinking number of AA-recipients, which is only partially compensated by a slightly rising number of municipal PA-recipients.

Can these figures be regarded as a sign of a trend reversal, as regards the process of defamilialization of disability support? The answer depends on whether the declining number of people included in the PA-system is regarded as an indication of declining support needs or rather as an expression of stronger admission restrictions.

\subsection{Approval Rate, Withdrawal Decisions and Assessment Criteria}

Figures on the approval rate for first-time AAapplications strongly suggest that rather the latter is the case (see figure 2, below). In 2005 about $70 \%$ of all AAapplications were approved. Around 2010 the approval rate hovered around $50 \%$. According to the most recent figures from January to June 2017 , now only $17 \%$ of all people seeking AA are admitted. The shrinking approval rate is not due to a rising number of applicants. By contrary, the absolute number of AA-applicants per year has been relatively stable since 2005 , hovering around 2,500 applications per year (SSIA, 2017b, p. 39).

It has not only become much harder to get access to AA for first-time applicants. Also, those who are already covered by AA run a heightened risk to lose their $A A$ at the two-year follow-up checkpoints. The proportion of follow-ups leading to AA-withdrawal has remained stable at around $8 \%$ in the period 2009-2016, yet it has doubled from 2016 to 2017 according to provisional figures from the SSIA (2017b, p. 52-53).

According to the SSIA's own analyses (2017a, 2017b) the development concerning approval and withdrawal rates is mostly due to sharpened assessment criteria. These have in turn partly been prompted by two Supreme Administrative Court (SAC) rulings from 2012 and 2015. The SAC-ruling from 2012 (HFD, 2012) prescribes that the need of assistance for medical self-care, such as assistance with ostomy, catheter and enteral nutrition cannot be regarded as a basic need in the sense of LSS (NBHW, 2017b, p. 19). Another SAC-decision from 2015 stipulates that only mental health problems can constitute other assistance needs, "requiring detailed knowledge of the person" (HFD, 2015). Therefore, for example, the need of assistance with breathing, handling of epileptic seizures, etc., would not constitute a PA need according to LSS (NBHW, 2017b, p. 19). Yet another SACdecision from July 2017 (HFD, 2017) was expected to drastically reduce the chances of applicants to receive AA in the future, prescribing that waiting hours and preparedness of PA-staff in between active assistance activ- 


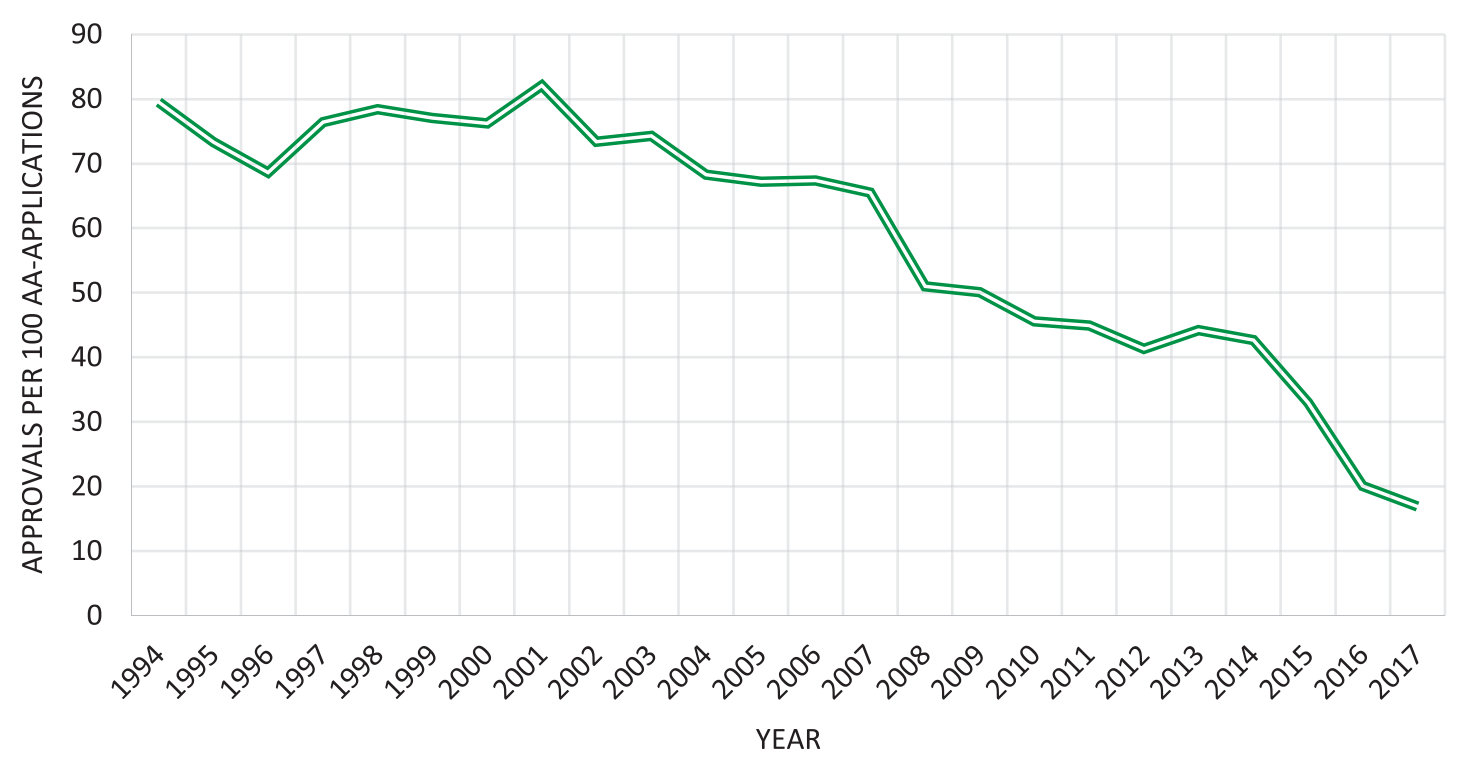

Figure 2. Approval rate for first-time AA-applications, 1994-2017. Sources: SSIA (2017a); data from SSIA retrieved from Independent Living Institute (2018).

ities shall not be counted when PA needs are calculated. The government has pledged to attempt to halt the potential impact of this recent court decision (Government of Sweden, 2018).

More recently, also governmental appropriation directives calling for cost containment have implicitly encouraged SSIA to sharpen admission criteria. The appropriation directive from 2015 explicitly instructed SSIA to "contribute to reduce the development of admitted hours in the Assistance Allowance" (Government of Sweden, 2015). SSIA has also on its own become active to tighten admission criteria for AA. Already in 2007 SSIA specified that in the future only "very personal" needs are to be regarded as basic needs in the sense of LSS (Näsman, 2016). SSIA now regards, for instance, certain forms of motivational assistance no longer as a basic need in the sense of LSS. When it comes to children applying for AA, it is often argued that motivational assistance as well as other types of assistance such as constant supervision can instead be expected to be a part of parents' "ordinary responsibility" for their children (SSIA, 2017a, p. 29). Therefore, particularly children with autism or similar conditions now run a much higher risk of nonapproval in admission or re-evaluation assessments. Yet, the chances of approval have shrunken for all categories covered by LSS (see SSIA, 2017a, pp. 19f).

Altogether, it can be concluded that the admission threshold for AA has substantially been raised. Only to a small extent the declining approval rate for AA has been compensated by a slightly rising influx of PA-applicants into municipal PA (see figures on municipal PA above).

\subsection{Service Intensity}

As we have seen above, the coverage of PA and, in particular, the admission chances for first-time PA-applicants have been reduced in the past recent years. Looking at intensity figures another trend can be observed (see Figure 3). The number of assistance hours granted per average AA-recipient has risen steadily since 1995, except for the last year. Looking at overall data covering both AA and municipal PA a slight decrease of the average service intensity per recipient can be observed, though, since an increasing proportion of those who get PA now must rely on municipal PA, which per definition has a lower service intensity.

How can we understand this trend? As said above, in the past decade it has become harder and harder to get admitted to $A A$, meaning that to an increasing extent only those with very extensive support needs are granted access to the PA-system. Hence, the observed trend simply mirrors the fact that PA has become more and more focused on people who need comprehensive assistance, whereas others are barred from access.

Altogether, the figures presented here suggest that the current Swedish PA-system is in a critical situation. Looking solely at long time series about coverage figures, no dramatic changes can be seen yet. However, digging deeper and focusing on the development of approval rates for first-time AA-applicants and analysing recent Administrative Court decisions another picture emerges, suggesting that we might be witnessing the very beginning of a dismantling of the universal and defamilializing character of Swedish PA. Access to AA now seems to be reserved for those with very extensive needs of assistance, whereas others who also may have substantial support needs mostly are declined access. When it comes to disabled children, PA is often declined with the explicit motivation that their parents can be expected to take care of their needs due to their legally stipulated parental responsibility (Fridström Montoya, 2017; SSIA, 2017b). 


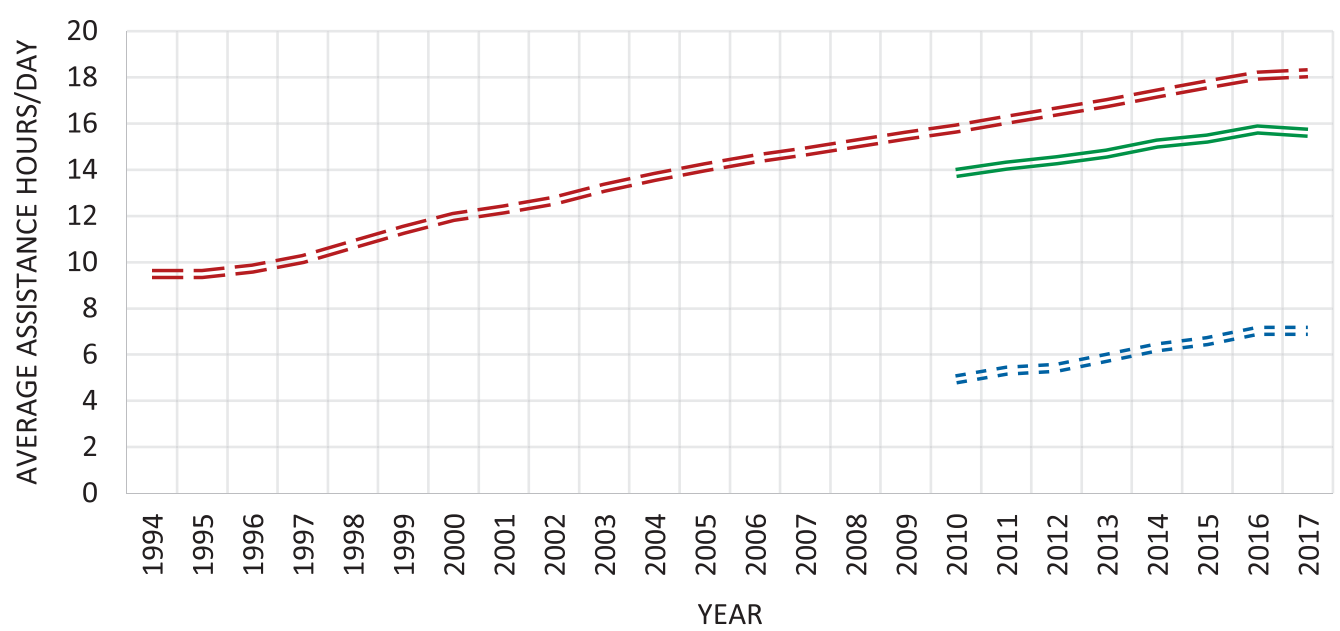

$==:$ AA-hours/day $===s$ : Municipal PA-hours/day $=$ Adj average PA-hours/day

Figure 3. PA-intensity, 1994-2017. Source: own calculations based on data from SSIA, retrieved from Independent Living Institute (2018).

\section{Discussion: Possible Consequences for Agency and Equality}

The figures above reveal that a large proportion of AAapplications are declined. In this section, we will discuss the possible consequences of AA-decline for the agency and the equality of the affected disabled people and their families.

\subsection{Agency}

In a recent enquiry, the Swedish NBHW has analyzed the fate of 460 disabled persons who have either been declined access to AA or have experienced withdrawn AA in the first half of 2017 (NBHW, 2017b). In this group, 40\% are children. According to NBHW's analyses many in this group have considerable support needs. Nevertheless, $20 \%$ are now without any support services whatsoever. Two thirds receive municipal PA, which, however, normally does not exceed 20 hours per week. Some receive other municipal services, such as relief care service in the home and short-term residential care. For most affected persons, all these alternative services have proven to be non-sufficient in relation to their needs of assistance. NBHW's report also reveals that close relatives of disabled people with declined AA very often have to take over a high support responsibility, which often is conceived as too high to be manageable. Because of that, an increasing number of disabled people end up in LSS-homes. Statistical data confirm that this form of residential disability support is on the rise again (NBHW, 2017a, p. 31).

From the enquiry of NBHW and also from another study carried out by Näsman (2016) yielding similar results, it can be concluded that AA-decline has huge consequences for the agency and the life chances of many disabled people and their relatives. The affected disabled people often become very strongly dependent on familial support or, alternatively, they will be bound to a residential support facility, which arguably hits their agency even more drastically. AA-decline also vastly deteriorates the agency of many relatives of disabled people with comprehensive support needs, who often are forced to abstain themselves from active participation in social life-including labor market participation-and to live with the social and material consequences thereof.

\subsection{Equality}

What then are the consequences for equality? Here we will distinguish between functionality related, gender related, class related and local equality.

\subsubsection{Functionality Related Equality}

One of the main ambitions of LSS is to further "equality in living conditions" and thus to allow disabled people with comprehensive support needs to "live as others" (SFS, 1993, 5§). This goal has probably never been fully met (von Granitz, Reine, Sonnander, \& Winblad, 2017), yet the rather unique universal and generous character of Swedish PA, allowed huge strides in the right direction in the period of PA-expansion. However, in the most recent years PA has become much weaker in terms of universalism and defamilialization of support responsibilities and, in consequence, also its agency boosting function has started to crumble. As argued above, the agency of many disabled people and their relatives has been reduced because of the tightened AA-assessment criteria. Following the argument of Sen (1992) that agency is a major dimension of equality, this implies that functionality related inequality is on the rise again.

\subsubsection{Gender Equality}

Given the fact that informal support is predominantly carried out by women, it is often argued that defamil- 
ialization primarily boosts the agency of women and, therefore, that it is an important precondition of gender equality (e.g., McLaughlin \& Glendinning, 1994; UImanen, 2015). Yet, in the current Swedish PA-system we are rather witnessing a refamilialization trend. Arguably, this trend most probably implies a deepening of gender inequality.

\subsubsection{Class Equality}

In the last decade, we have seen a rise of commercial household services in Sweden, prompted by the introduction of an earmarked tax deduction for the purchase of these services in 2006 (Erlandsson, Storm, Stranz, Szebehely, \& Trydegård, 2013). We know that a significant portion of older persons resorts to these kind of services as an alternative to home help services (Erlandsson et. al, 2013; Ulmanen \& Szebehely, 2015) and there have been rumors in the press that disabled people with declined PA are starting to do the same. Can these commercial services to some extent compensate for the decreased public PA-provision?

Some social policy researchers do conceive commercial personal services as a possible alternative route towards defamilialization (Esping-Andersen, 1999; Saraceno, 2010). However, the problem with this second route of defamilialization is that it is only accessible for the economically privileged. Only publicly regulated services are granted universally, based on citizenship and/or needs. Commercial services are instead allocated after purchasing power. Figures about the consumption of commercial services among older people reveal that these services are indeed foremost consumed by high income groups (Erlandsson et al., 2013; Ulmanen \& Szebehely, 2015). Most probably we would see the same situation in the field of disability support: in case of declined or insufficient PA, only the affluent can afford to purchase commercial support alternatives, but not the less affluent, who only can resort to familial support. Hence, we can conclude that we will end up with a segmented defamilialization of support, if commercial services replace publicly administered PA to a significant extent. In other words, the current development of PA might in the longer run also imply a deepened class related inequality among disabled people who are excluded from AA. People with lower education already are underprivileged when it comes to PA-access, since they are less likely to have the capacity to effectively claim their social rights, in particular if they are required to take up a legal fight against authorities.

\subsubsection{Local Equality}

One of the main reasons behind the introduction of $A A$ and the related transfer of the main admission approval responsibility to the SSIA, was to establish a uniform admission standard across the country (Näsman, 2016). Ironically, the recent development of AA forces many PA applicants to apply for municipal PA. Yet, Swedish municipalities employ very different admission criteria and therefore the chances of PA applicants to be at least admitted municipal PA differ substantially between municipalities (NBHW, 2017b). Moreover, the possibility to purchase commercial service alternatives varies greatly across the country. These services tend to be available only in densely populated areas (Erlandsson et al., 2013). Altogether, this means that the recent sharpening of admission criteria for AA most probably also engenders an increasing local inequality among disabled in need of support.

\section{Conclusion}

The Swedish disability support system is often praised by international observers. PA is conceived as the crown jewel of this system. It is assumed to be universally accessible for all disabled people with comprehensive needs of assistance. Due to this assumed character, Swedish PA is believed to effectively enable disabled people and their relatives to lessen their mutual dependency, to boost their agency and to enhance their social position in society. This image of Swedish PA has been underpinned by statistical data witnessing a constantly rising relative number of PA-recipients from the introduction of LSS in 1994 up until about 2010-2011.

Yet, data from the past decade about approval rates for AA-seekers as well as analyses of changed admission criteria suggest, that we might be in the wake of a reversed development. Potential newcomers to the PA-system meet drastically decreased chances to pass the admission tests. Those already covered by PA run a heightened risk to lose their PA, when their assistance needs are scrutinized in their next re-assessment. Not only disabled people with minor support needs are affected, but also certain groups who according to a common-sense definition of comprehensive disability should qualify for $A A$, such as persons with physical impairments in need of breathing assistance or children with autism in need of motivational assistance. If this recent trend continues, we might very well be witnessing the very beginning of the dismantling of PA as a universal support system for disabled people with substantial support needs.

There will definitely be consequences both on the individual and the societal level if this trend is allowed to continue. On the individual level, we will see that an everlarger number of disabled people will have to turn to municipal service alternatives, which do not have the capacity or quality to fully satisfy their support needs (Näsman, 2016). As a result, a large group of disabled people and their relatives will be exposed to increased familial dependency, a low level of agency and consequently reduced life chances both in economic and other terms (Näsman, 2016; NBHW, 2017b).

In the long run, there will also be consequences on the societal level, both in terms of inequality and eco- 
nomic sustainability. A dwindling state sponsored disability support means more inequality (both in terms of economic resources and agency) between disabled and their relatives on one hand, and those unaffected by disability on the other. Female relatives will be particularly hit by diminished agency and therefore also gender equality will be influenced negatively. A rising proportion of disabled people, will need to find alternative support solutions. Yet, commercial service alternatives that potentially can replace familial support are only accessible for the economically privileged and thus also class differentials will rise within the group of disabled and their families. Interestingly, the recent trend of PA-austerity can also be questioned from a strict economic standpoint. As Knutsson (2017) and Näsman (2016) have argued, the economic savings from reducing access to PA are most probably much lower than the alternative costs in terms of shrinking employment activity and heightened dependency on welfare benefits among disabled and their relatives. Altogether, it can be argued that a continued austerity in the PA-sector most probably will be detrimental for both the social and the economic sustainability of the Swedish society.

The recent trend in the PA-sector can only be reverted if we understand its main causes. The governmental appropriation directive from 2015 suggests that cost containment motives might be one important cause behind the most recent sharpening of admission criteria. Most certainly, vagueness in the stipulations of LSS about what needs constitute basic needs is another important cause. This vagueness has made possible the recent SAC rulings (Näsman, 2016). Political decision-makers will have to re-evaluate both the recent cost containment strategy as well as the legal design of LSS if they want to save the Swedish PA-system from collapse. But they will have to act swiftly to get the actual development of the system back into line with the universal and emancipatory ambition of LSS. If decision makers rather choose to take a passive stance, the universal, empowering and equalizing PA-system that we have come to know will disappear and will be replaced by a more old-fashioned system, characterized by familial dependency, poor agency and much less equality-a system that not only would be disadvantageous for the affected disabled people and their families, but also for society as a whole.

\section{Acknowledgements}

This research was supported by the Swedish Research Council for Health, Working Life and Welfare (Forskningsrådet för Hälsa, Arbetsliv och Välfärd), grant number 2012-0275.

\section{Conflict of Interests}

The authors declare no conflict of interests.

\section{References}

Anttonen, A. (2003). Working parents and the welfare state: Family change and policy reform in Scandinavia. Journal of European Social Policy, 13(3), 304-305.

Askheim, P. O., Bengtsson, H., \& Bjelke, B. R. (2014). Personal assistance in a Scandinavian context: Similarities, differences and developmental traits. Scandinavian Journal of Disability Research, 16(sup1), 3-18.

Dunér, A., \& Olin, E. (2018). Personal assistance from family members as an unwanted situation, an optimal solution or an additional good? Disability \& Society, 33(1), 1-19.

Erlandsson, S., Storm, P., Stranz, A., Szebehely, M., \& Trydegård, G.-B. (2013). Marketising trends in Swedish eldercare: Competition, choice and calls for stricter regulation. In G. Meagher \& M. Szebehely (Eds.), Marketisation in Nordic eldercare (pp. 23-83). Stockholm: Stockholm University.

Esping-Andersen, G. (1999). Social foundations of postindustrial economies. New York, NY: Oxford University Press.

Fridström Montoya, T. (2017). Ole, dole, doff: Vilken tid ska bort? Om föräldraansvaret vid bedömningar av rätt till personlig assistans för barn med funktionsnedsättningar. In M. Brattström \& M. JänteräJareborg (Eds.), För Barns bästa. Vänbok till Anna Singer (pp. 87-107). Uppsala: Iustus Förlag.

Government of Sweden. (2015). Regleringsbrev för budgetåret 2016 avseende Försäkringskassan (Regeringsbeslut I:8) Stockholm: Government of Sweden.

Government of Sweden. (2018). Nya assistansregler föreslås träda $i$ kraft 1 april (Press Release, 2018/01/08). Retrieved from http://www. regeringen.se/pressmeddelanden/2018/01/nya-assi stansregler-foreslas-trada-i-kraft-1-april

HFD. (2012). Supreme administrative court annual book HFD 2012 ref. 41 (case number: 1-12).

HFD. (2015). Supreme administrative court annual book HFD 2015 ref. 46 (case number: 3527-14).

HFD. (2017). Supreme administrative court annual book HFD 2017 ref. 27 (case number: 1206-16). Independent Living Institute. (2018). Statistik om personlig assistans. Assistancoll. Retrieved from https:// assistanskoll.se/assistans-statistik.php

Knutsson, H. (2017). Den personliga assistansens alternativkostnader. Lund: Lund University.

Leitner, S., \& Lessenich, S. (2007). (In)dependence as dependent variable: Conceptualizing and measuring 'de-familization'. In H. Clasen \& N. A. Sigel (Eds.), Investigating welfare state change (pp. 244-260). Cheltenham: Edward Elgar.

Lewis, J. (2001). The decline of the male breadwinner model: Implications for work and care. Social Politics, 8(2), 152-169.

Lister, R. (1994). "She has other Duties"-Women, citizenship and Social Security. In S.Baldwin \& J. Falkingham (eds.) Social security and social change: 
New challenges to the Beveridge model (pp. 31-40). Hemel Hemstead: Harvester Wheatsheaf.

Lohmann, H., \& Zagel, H. (2015). Family policy in comparative perspective: The concepts and measurement of familization and defamilialization. Journal of European Social Policy, 26(1), 48-65.

McLaughlin, E., \& Glendinning, C. (1994). Paying for care in Europe. Is there a feminist approach? In L. Hantrais \& S. Mangen (Eds.), Family policy and the welfare of women (pp. 52-69). Leicestershire: Loughborough University of Technology.

Näsman, M. (2016). Konsekvenser av indragen assistansersättning. En studie om medikalisering och hur kostnader skiftar från samhället till brukaren och dess anhöriga. Umeå: Umeå University.

NBHW. (2017a). Insatser och stöd till personer med funktionsnedsättning. Lägesrapport 2017. Stockholm: Socialstyrelsen.

NBHW. (2017b). Konsekvenser av domar om det femte grundläggande behovet. En analys av hur kommuner och brukare påverkas. Stockholm: NBHW.

O'Connor, J. (1993). Gender, class and citizenship in the comparative analysis of welfare state regimes: Theoretical and methodological issues. British Journal of Sociology, 44(3), 501-518.

Rauch, D. (2007). Is there really a Scandinavian social service model? A comparison of childcare and elderlycare in six European countries. Acta Sociologica, 50(3), 249-269.

Saraceno, C. (2010). Towards an integrated approach for the analysis of gender equity in policies supporting paid work and care responsibilities. Demographic $R e$ search, 25, 371-405.

Sen, A. (1992). Inequality reexamined. New York, NY: Russel Sage Foundation.

SFS. (1993). Act concerning support and services to per- sons with certain functional impairments (Swedish Code of Statutes SFS 1993:387). Stockholm: Ministry of Health and Social Affairs.

Sipilä, J. (1997). Social care services: The key to the Scandinavian welfare model. Aldershot: Avebury.

SSIA. (2016). Assistansersättningens utveckling. Förändringsprocesser 2005-2015 (Social Insurance Report 2016:5). Stockholm: SSIA.

SSIA. (2017a). Avslag inom assistansersättningen. Hur kan vi förstå den senaste tidens ökning? (Social Insurance Report, 2017:8). Stockholm: SSIA.

SSIA. (2017b). Assistansersättning. Inflöde, utflöde och konsekvenser av förändrad rättspraxis (Social Insurance Report 2017:14). Stockholm: SSIA.

Statistics Sweden (2018). Statistical database. Statistik databasen. Retrieved from http://www.statistikdata basen.scb.se/pxweb/en/ssd/?rxid=86abd797-78544564-9150-c9b06ae3ab07

Szebehely, M., \& Trydegård, G.-B. (2007). Omsorgstjänster för äldre och funktionshindrade: Skilda villkor, skilda trender? Socialvetenskaplig tidskrift, 14(2/3), 197-219.

Ulmanen, P. (2015). Omsorgens pris $i$ åtstramningstid: Anhörigomsorg för äldre ur ett könsperspektiv (PhD dissertation). Stockholm University, Stockholm.

Ulmanen, P., \& Szebehely, M. (2015). From the state to the family or to the market? Consequences of reduced residential eldercare in Sweden. International Journal of Social Welfare, 24(1), 81-92.

Ungerson, C. (1997). Social politics and the commodification of care. Social Politics, 43(3), 583-600.

von Granitz, H., Reine, I., Sonnander, K., \& Winblad, U. (2017). Do personal assistance activities promote participation for persons with disabilities in Sweden? Disability and Rehabilitation, 39(24), 2512-2521.

\section{About the Authors}
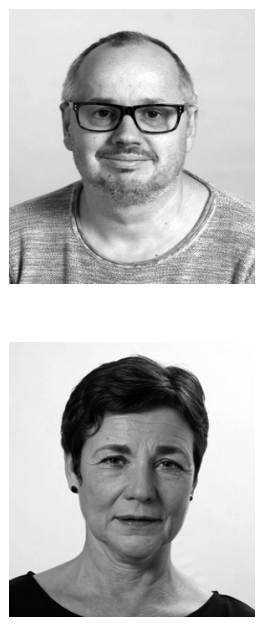

Dietmar Rauch is Senior Lecturer in social work. His research areas are social policy, social care services and old age policy.

Elisabeth Olin is Professor in social work. Her research concerns the life situation of disabled people, primarily related to various aspects of their daily living, social relationships and participation in society. 


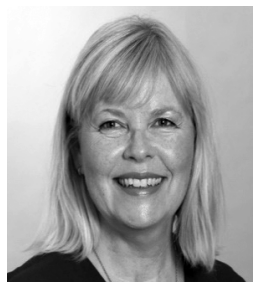

Anna Dunér is Professor in social work. Her research areas are formal and informal support networks, and social work with older and disabled people. 